\title{
OTONOMI DAERAH DAN PENINGKATAN KESEJAHTERAAN (STUDI MENGENAI PEMEKARAN DI KABUPATEN KAMPAR DAN KABUPATEN ROKAN HULU PROPINSI RIAU)
}

\author{
Wahidin \\ wahidin@uin-suska.ac.id, Universitas Islam Negeri Sultan Syarif kasim \\ Riau \\ Firdaus \\ firdaus@uin-suska.ac.id, Universitas Islam Negeri Sultan Syarif kasim \\ Riau \\ M. Ihsan \\ m.ihsan@uin-suska.ac.id, Universitas Islam Negeri Sultan Syarif kasim \\ Riau
}

\begin{abstract}
Regional expansion has the potential to lead to progress or setback for a region because regional expansion is vulnerable in the stages of regional government development. Various studies have shown that in the context of expansion, increasing welfare implies various problems in the implementation of regional autonomy policies. For this reason, in this study the authors took a sample of the Riau province which has experienced several regional expansion, especially the Rokan Hulu Regency, as an expansion area of Kampar Regency. This research is a filed research research with a doctrinal research approach in which literature review becomes the primary data in the form of community welfare indicators. Data collection was carried out by interview and documentation study. Through this research, it was found that post-Reformation Rokan Hulu district has developed into an area that is not only able to follow various welfare indicators from its parent region of Kampar district but also even acculturation of the immigrant community culture has made this district independent.
\end{abstract}

Keywords: welfare, regional expansion, regional autonomy

\begin{abstract}
Abstrak
Pemekaran wilayah berpotensi menimbulkan kemajuan atau kemunduran bagi suatu daerah karena pemekaran wilayah bersifat rentan dalam tahapan perkembangan pemerintahan daerah. Berbagai studi menunjukkan bahwa dalam konteks pemekaran, peningkatan kesejahteraan menyiratkan berbagai permasalahan dalam implementasi kebijakan otonomi daerah. Untuk itu dalam penelitian ini penulis mengambil sampel daerah propinsi Riau yang telah mengalami beberapa kali pemekaran daerah khususnya daerah Kabupaten Rokan Hulu,
\end{abstract}


sebagai daerah pemekaran dari Kabupaten Kampar. Penelitian ini adalah penelitian filed research dengan pendekatan doctrinal research dimana kajian kepustakaan menjadi data primerdalam bentuk indikator kesejahteraan masyarakat. Pengumpulan data dilakukan dengan wawancara dan studi dokumentasi. Melalui penelitian ini ditemukan bahwa kabupaten Rokan Hulu pasca Reformasi telah berkembang menjadi daerah yang tidak hanya mampu menyusul berbagai indicator kesejahteraan dari wilayah induknya kabupaten Kampar namun juga bahkan akulturasi budaya masyarakat pendatang telah menempatkan kabupaten ini menjadi mandiri.

Kata Kunci: kesejahteraan, pemekaran wilayah, otonomi daerah

\section{Pendahuluan}

Faktor utama pemekaran wilayah atau suatu daerah ialah tidak terkonsentrasinya pembangunan dari berbagai sektor kehidupan di wilayah yang disinyalir berkompeten. Tentunya, kebutuhan pemekaran wilayah atau daerah tersebut mendorong pemenuhannya dengan cara pemisahan dari induk pemerintahan. Namun, pemekaran wilayah bukan sekadar rencana yang dengan cepat terasa perubahan kemajuannya. Bisa saja, pemekaran wilayah akan menimbulkan salah satu kemunduran pembangunan, karena pemekaran wilayah cenderung bersifat rentan harus memulai dari titik awal segala kebutuhan suatu pembentukan pemerintahan.

Berdasarkan hasil dari berbagai studi bahwa studi tentang otonomi daerah dalam konteks pemekaran dan peningkatan kesejahteraan menyiratkan berbagai permasalahan dalam implementasi kebijakan otonomi daerah. Sebagai sebuah kebijakan yang didasari pendekatan hukum maka seyogyanya berbagai persoalan tersebut diidentifkasi melalui diskursus pemikiran hukum yang mencakup berbagai disiplin ilmu di bidang hukum antara lain teori hukum, filsafat hukum, sosiologi hukum, politik hukum dan lain sebagainya. Di samping itu fenomena otonomi daerah yang sering diidentikkan dengan pemekaran wilayah tidak dapat dipisahkan dari sisi kearifan lokal yang dapat menjelaskan karakteristik persoalan otonomi yang berbeda di setiap daerah. Untuk itu dalam penelitian ini penulis mengambil sampel daerah propinsi Riau yang telah mengalami beberapa kali pemekaran daerah khususnya daerah Kabupaten Rokan Hulu, sebagai daerah pemekaran dari Kabupaten Kampar pada 4 Oktober 1999. ${ }^{1}$ Otonomi daerah yang pada prinsipnya bermakna kemandirian, mengharuskan daerah kabupaten dan kota mengelola kelangsungan hidupnya atas kemampuan sendiri, berkembang secara dinamis dan memenuhi segenap kemandirian itu. Riau terutama

1 Tri Ratnawati, Pemekaran Daerah; Politik Lokal dan Beberapa Isu Terseleki Pustaka Pelajar ,Yogyarta: 2009, hlm. 90 
pasca reformasi, mulai menggeliat sebagai propinsi dengan pertumbuhan ekonomi dan pembangunan sangat pesat. ${ }^{2}$

Untuk itu persoalan otonomi daerah semestinya dikaji dari kaca mata ilmu hukum mengingat kebijakan ini lahir akibat perubahan peraturan hukum mengenai pembagian kekuasaan daerah dan pusat. Untuk itu melalui penelitian ini penulis akan berupaya mengeksplorasi persoalan otonomi daerah dalam perspektif hukum serta implikasinya terhadap kesejahteraan masyarakat di wilayah pemekaran.

\section{Kajian Pustaka}

\section{Tinjauan Tentang Otonomi dan Pemekaran Daerah}

Legalisasi pemekaran wilayah dicantumkan dalam pasal yang sama pada ayat berikutnya ayat (3) yang menyatakan bahwa, "Pembentukan daerah dapat berupa penggabungan beberapa daerah atau bagian daerah yang bersandingan atau pemekaran dari satu daerah menjadi dua daerah atau lebih". Dan ayat (4) menyebutkan, "Pemekaran dari satu daerah menjadi 2 (dua) daerah atau lebih sebagaimana dimaksud pada ayat (3) dapat dilakukan setelah mencapai batas minimal usia penyelenggaraan pemerintahan".

Secara teknis, aturan mengenai tata cara pembentukan daerah di atur dalam PP No. 129 tahun 2000 dan PP No. 78 tahun 2007 tentang Persyaratan Pembentukan dan Kriteria Pemekaran, Penghapusan dan Penggabungan Daerah. Syarat teknis meliputi faktor yang menjadi dasar pembentukan daerah yang mencakup faktor kemampuan ekonomi, potensi daerah, sosial budaya, sosial politik, kependudukan, luas daerah, pertahanan, keamanan, dan faktor lain yang memungkinkan terselenggaranya otonomi daerah. Syarat fisik meliputi paling sedikit 5 (lima) kabupaten/kota untuk pembentukan provinsi dan paling sedikit 5 (lima) kecamatan untuk pembentukan kabupaten, dan 4 (empat) kecamatan untuk pembentukan kota, lokasi calon ibukota, sarana, dan prasarana pemerintahan.

\section{Hubungan Pemekaran Daerah dengan Peningkatan Kesejahteraan}

Pemekaran daerah merupakan suatu proses pembagian wilayah menjadi lebih dari satu wilayah, dengan tujuan meningkatkan pelayanan dan mempercepat pembangunan. Pemekaran wilayah juga diharapkan dapat menciptakan kemandirian daerah. Tujuan pemekaran sebagaimana tertuang dalam berbagai peraturan perundangan dimaksudkan untuk meningkatkan kesejahteraan masyarakat melalui:

1. Peningkatan pelayanan kepada masyarakat;

${ }^{2}$ Suwardi, MS dkk., Sejarah Perjuangan Rakyat Riau, Buku II, Unri Press , Pekanbaru: 2004, Unri Press, hlm. 309 
2. Percepatan pertumbuhan kehidupan demokrasi;

3. Percepatan pelaksanaan pembangunan perekonomian daerah;

4. Percepatan pengelolaan potensi daerah;

5. Peningkatan keamanan dan ketertiban.

Pemekaran bagi masyarakat daerah merupakan kemestian yang tidak boleh ditawar bilamana dihubungkan dengan, misalnya: ${ }^{3}$

1. Ketimpangan pembangunan (ekonomi) dan rendahnya pelayanan publik yang dirasakan oleh daerah. Ada logika mengebelakangkan pembangunan dan/atau melaksanakan pelayanan secara asimeteris oleh daerah induk pada daerah-daerah yang dimekarkan;

2. Eksploitasi oleh daerah induk pada daerah calon pemekaran. Oleh karena alasan kepemilikan atas kekayaan sumberdaya alam (SDA) inilah yang mendorong daerah melakukan pemekaran. Alasan ini diperkuat dengan sejarah selama pemerintahan orde sebelumnya, daerah ini selalu diekplorasi dan dieksploitasi besar-besaran tanpa menghiraukan daerah sumber. Ini kembali terjadi pada era-otonomi daerah selepas Orde Baru. Putusan terbaik dari kemajuan yang diharapkan hanyalah memisahkan diri, agar mereka merasakan kekayaan mereka sendiri;

Indikator-indikator kesejahteraan pada dasarnya merupakan induksi dari kriteria pemekaran daerah yang termuat dalam PP no 129 tahun 2000 yang menggambarkan indikator input maupun output pada aspek-aspek di atas. Dengan demikian dapat dirumuskan bahwa indikator untuk menentukan peningkatan kesejahteraan masyarakat adalah sebagai berikut:

1. Kinerja Ekonomi Daerah. Fokus kinerja ekonomi digunakan untuk mengukur, apakah setelah pemekaran terjadi perkembangan dalam kondisi perekonomian daerah atau tidak. Indikator yang akan digunakan sebagai ukuran kinerja ekonomi daerah adalah Pertumbuhan PDRB Non-migas (ECGI), PDRB per Kapita (WELFI), Rasio PDRB Kabupaten Terhadap PDRB Propinsi (ESERI) dan Angka Kemiskinan (POVEI).

a. Kinerja Keuangan Pemerintah Daerah dengan indikator Ketergantungan Fiskal (FIDI), Kapasitas Penciptaan Pendapatan (FGII) Proporsi Belanja Modal (FCAPEXI) dan Kontribusi Sektor Pemerintah (FCEI)

b. Kinerja Pelayanan Publik. Evaluasi kinerja pelayanan publik mencakup pelayanan bidang pendidikan, kesehatan dan infrastruktur dengan indikator yang digunakan pendidikan, kesehatan dan infra struktur

${ }^{3}$ Leo Agustino, Ketimpangan Otonomi Daerah, Penulis: http://www.pikiranrakyat.com/prprint.php?mib=beritadetail\&id=57603, terakhir kali diakses tanggal 16 Februari 2017. 
c. Kinerja Aparatur Pemerintah Daerah untuk mengetahui seberapa jauh ketersediaan aparatur dapat memenuhi tuntutan pelayanan kepada masyarakat.

\section{Metode Penelitian}

Jenis penelitian ini adalah penelitian campuran antara observation research dan doctrinal research. Dengan demikian penelitian ini mengkaji diskursus pemikiran ilmu hukum tentang otonomi daerah berdasarkan pendekatan doctrinal research dengan melakukan kajian kepustakaan terhadap berbagai aturan normatif bidang otonomi daerah mulai dalam berbagai hirarki peraturan perundang-undangan.

Data yang penulis peroleh dianalisis melalui metode deskriptif analitatif melalui pengkualifikasian data sesuai dengan kelompoknya kemudian diolah dan disajikan dalam bentuk tabel. Data atau informasi yang diperoleh melalui teknik wawancara disajikan dalam bentuk uraian kalimat. Kemudian kedua data tersebut dianalisis secara kualitatif dan menghubungkannya dengan peraturan perundang-undangan, pandangan para ahli serta data lainnya yang keseluruhannya relevan dengan penelitian dan disajikan secara deskritif.

4. Hasil Penelitian dan pembahasan (Otonomi Daerah Dan Peningkatan Kesejahteraan (Studi Mengenai Pemekaran di Kabupaten Kampar Dan Kabupaten Rokan Hulu Propinsi Riau)).

Pasca pemekaran wilayah, kabupaten rokan Hulu sebagai daerah baru menghadapi tantangan yang sedemikian dengan potensi yang tersedia, kabupaten ini segera berbenah diri baik secara struktural maupun sistem pemerintahan. Menjawab tantangan dan peluang ini, setelah secara resmi Kabupaten Rokan Hulu didirikan berdasarkan UU no. 53 tahun 1999 serta Keputusan Menteri Dalam Negeri RI no. 75 tahun 1999, pusat administratif pemerintahan dilaksanakan di kota Pasir Pengarayan. Sebagai kabupaten baru, daerah ini berpacu dengan berbagai potensi yang dimilikinya, baik dari sumber daya alam, penduduk, geografis wilayah, serta sarana infra struktur yang sudah ada.

Jumlah ini mengalami peningkatan tiap tahunnya dan terdistribusi di berbagai kecamatan dengan tingkat kepadatan yang berbeda. Hal ini dapat dilihat dalam tabel berikut: 


\begin{tabular}{|l|l|l|l|l|l|l|l|}
\hline NO & Kecamatan & 1994 & 1995 & 1996 & 1997 & 1998 & 1999 \\
\hline 1 & $\begin{array}{l}\text { Rambah + } \\
\text { Rbh Hilir }\end{array}$ & 74.694 & 75.599 & 57.756 & 58.050 & 58.902 & \\
\cline { 1 - 4 } & $\begin{array}{l}\text { Rambah } \\
\text { Samo }\end{array}$ & & & 17.979 & 17.879 & 17.644 & 17.657 \\
\hline 3 & Tandun & 37.159 & 39.259 & 43.287 & 43.491 & 43.821 & 43.901 \\
\hline 4 & $\begin{array}{l}\text { Kunto } \\
\text { Darussalam }\end{array}$ & 32.674 & 32.791 & 32.970 & 33.074 & 34.981 & 38.412 \\
\hline 5 & $\begin{array}{l}\text { Rokan IV } \\
\text { Koto }\end{array}$ & 20.281 & 20.325 & 21,311 & 21.429 & 21.593 & 21.665 \\
\hline 6 & $\begin{array}{l}\text { Tambusai }+ \\
\text { Tbs Utara }\end{array}$ & 33.675 & 34.245 & 36.545 & 40.007 & 41.104 & 41.766 \\
\hline 7 & Kepenuhan & 12.910 & 12.647 & 14.296 & 13.860 & 17.688 & 17.707 \\
\hline & JUMLAH & 211.39 & 213.86 & 224.14 & 227.79 & 237.73 & 240.61 \\
& 3 & 6 & 4 & 0 & 3 & 2 \\
\hline
\end{tabular}

Seiring dengan otonomi daerah dan percepatan pembangunan, penduduk Rokan hulu mengalami pertumbuhan yang signifikan. Dalam hal kependudukan, hingga tahun 2016 tercatat jumlah penduduk Kab. Rokan Hulu telah mencapai 360.992 jiwa dengan kepadatan penduduk rata-rata 48 jiwa/km2. sebagaimana tergambar dari tabel berikut:

Perkembangan Jumlah Penduduk Kab. Rokan Hulu pada tahun 2009-2016

\begin{tabular}{|c|c|c|c|c|c|c|c|c|}
\hline TAHUN & 2017 & 2016 & 2015 & 2014 & 2013 & 2012 & 2011 & 2010 \\
\hline $\begin{array}{l}\text { Jumlah } \\
\text { Pria } \\
\text { (jiwa) }\end{array}$ & $\begin{array}{l}334, \\
324\end{array}$ & $\begin{array}{l}323 \\
129\end{array}$ & $\begin{array}{l}303, \\
534\end{array}$ & $\begin{array}{l}281 . \\
915\end{array}$ & $\begin{array}{l}267 . \\
725\end{array}$ & $\begin{array}{l}254 . \\
498\end{array}$ & $\begin{array}{l}245 . \\
620\end{array}$ & 245.636 \\
\hline $\begin{array}{l}\text { Jumlah } \\
\text { Wanita }\end{array}$ & $\begin{array}{l}308 \\
607\end{array}$ & $\begin{array}{l}298 \\
273\end{array}$ & $\begin{array}{l}280 \\
186\end{array}$ & $\begin{array}{l}261 . \\
942\end{array}$ & $\begin{array}{l}249 . \\
852\end{array}$ & $\begin{array}{l}237 . \\
508\end{array}$ & $\begin{array}{l}229 . \\
223\end{array}$ & 229.375 \\
\hline
\end{tabular}




\begin{tabular}{|l||l||l||l||l|l|l||l|l|}
\hline (jiwa) & & & & & & & & \\
\hline Total & 642, & 621, & 583, & 543. & 517. & 492. & 474. & 475.011 \\
(jiwa) & 931 & 402 & 720 & 857 & 577 & 006 & 843 & 475 \\
\hline
\end{tabular}

Sumber: Kabupaten Rokan Hulu dalam Angka tahun 2017

\section{Kinerja Ekonomi Daerah}

Kinerja pertumbuhan ekonomi paling utama adalah pertumbuhan ekonomi yang dapat menjadi acuan data mengenai arah perekonomian daerah tersebut. Pertumbuhan ekonomi yang baik juga harus diikuti oleh pemerataan kesejahteraan masyarakatnya. Pertumbuhan ekonomi Kabupaten Rokan Hulu pada tahun 2017 lebih baik dibandingkan tahun 2016. Dari 3 sektor yang memiliki share yang tertinggi terhadap perkonomian di Kabupaten Rokan Hulu juga menunjukkan keadaan yang lebih baik dibandingkan tahun sebelumnya. Pertumbuhan ekonomi Kabupaten Rokan Hulu pada tahun 2017 sebesar 5,56 persen. Struktur perekonomian Kabupaten Rokan Hulu didominasi oleh 2 (dua) sektor yaitu pertanian dan industri pengolahan. Selama 5 (lima) tahun terakhir sektor pertanian tetap mendominasi struktur perekonomian Kabupaten Rokan Hulu. Perkebunan kelapa sawit dan karet yang menjadi penunjang di sektor pertanian ini. Secara ringkas pertumbuhan ekonomi kabupaten Rokan Hulu dapat dilihat dalam grafik berikut:

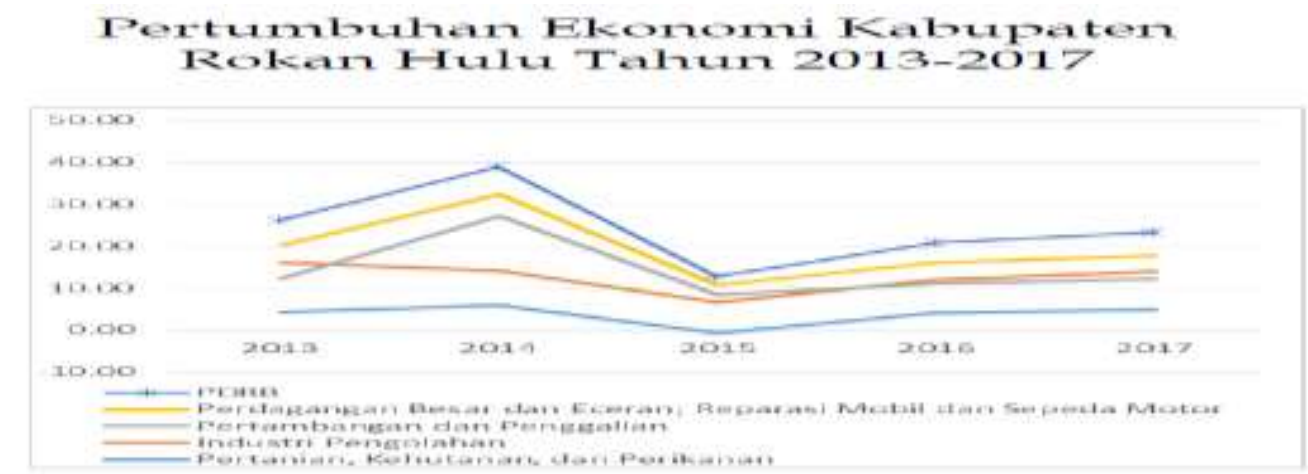

Selanjutnya kinerja ekonomi ditentutan angka PDRB baik dari segi harga berlaku maupun harga konstan terus meningkat . adapun 
perbandingan PDRB Kabupaten Rokan Hulu atas harga Baku dan kontsan dapat dilihat pada grafik berikut:

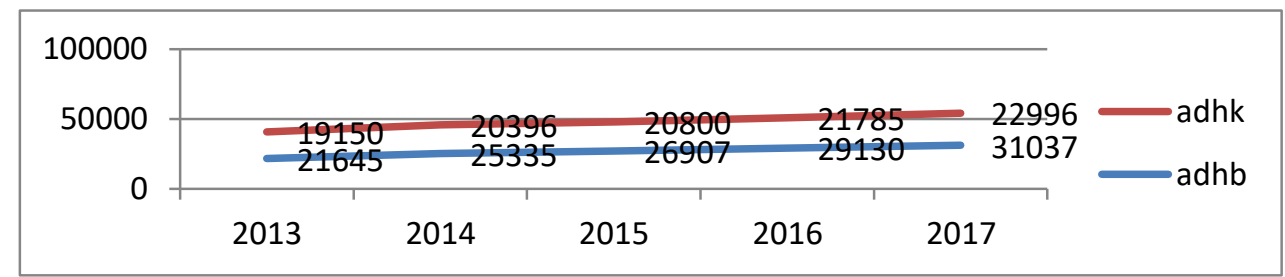

Bila dibandingkan dengan PDRB kabupaten Kampar dapat dilihat sebagai berikut:

Konstan 2010 Menurut Pengeluaran, Kabupaten Kampar 2013-2017

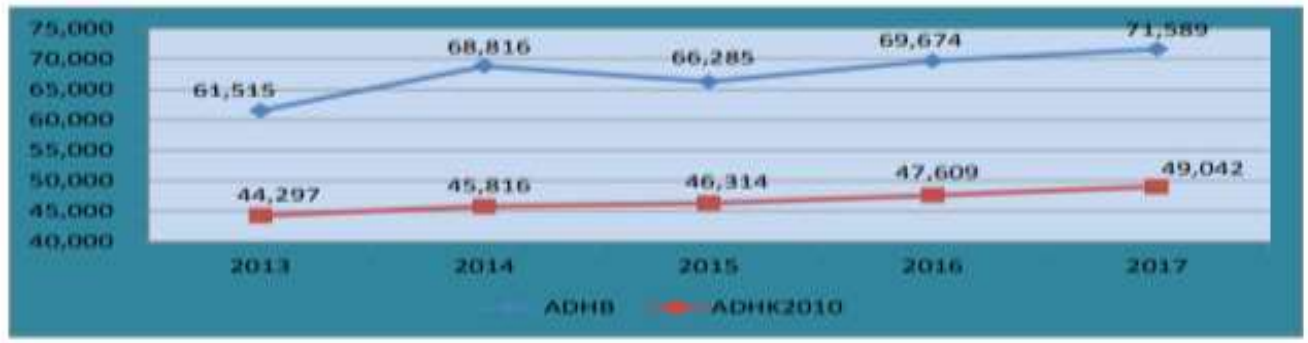

Dapat dilihat bahwa pada indeks PDRB baik atas harga konstan maupun baku pertumbuhan PDRB kabupaten rokan hulu terlihat mengalami kenaikan secara terus menerus. Dibandingkan kabupaten Kampar terlihat ada fluktuasi dimana ADHB mengalami penurunan pada tahun 2015. Hal ini menunjukkan Angka PDRB baik dari segiharga berlaku maupun harga konstan terus meningkat dapat dilihat pada grafik di samping. Dan pendapatan perkapita masyarakat Kabupaten Rokan Hulu pada tahun 2017 sebesar 48,41 juta naik jika dibandingkan pada tahun 2016 hanya sebesar 47,25 juta. Hal menarik lainnya adalah perbandingan PDRB atas migas dan non migas. Kabupaten ROkan Hulu daklam hal ini lebih cenderung untuk tidak bergantung pada migas dibandingkan kabupaten Kampar, kafrena beberapa blok penghasil minyak ada di kabupaten Kampar. Dibandingkan dengan kawasan kabpupaten dan kota di propinsi Riau dapat dilihat dalam table berikut: 


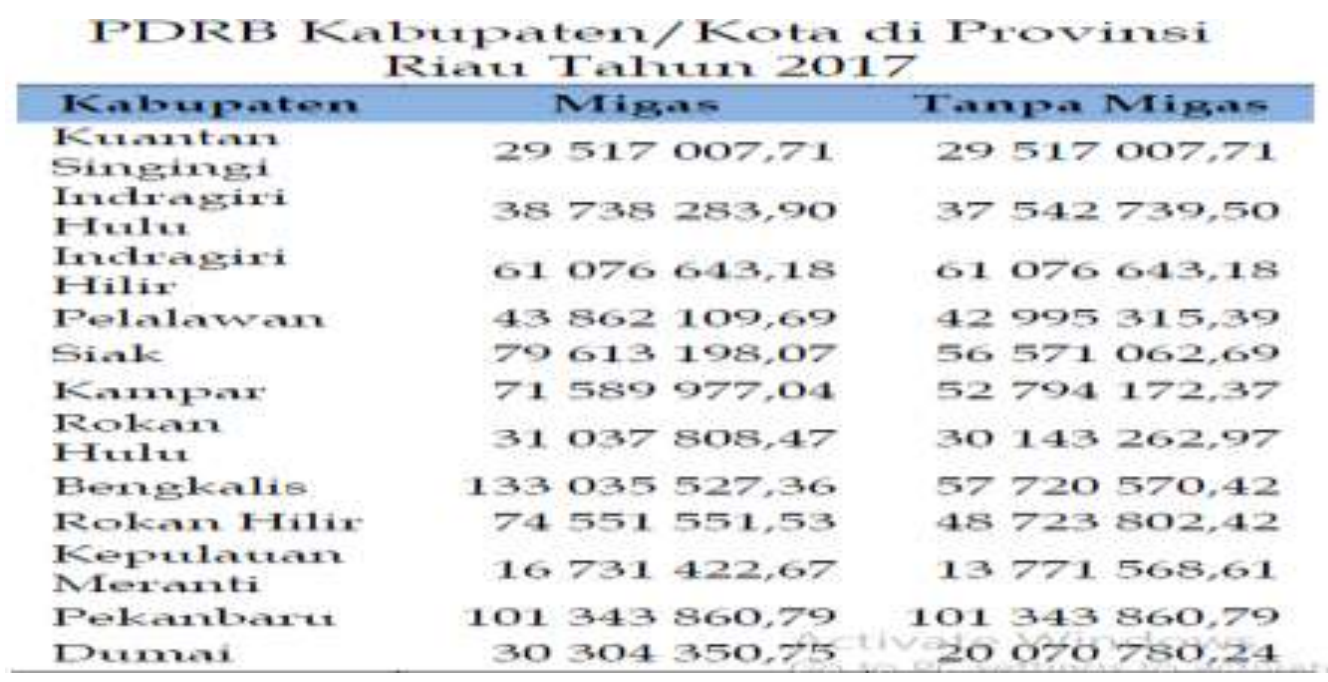

Dalam perspektif ekonomi kabupaten Rokan Hulu setelah otonomi daerah menunjukkan laju pertumbuhan ekonomi yang cukup besar bahkan di atas rata-rata pertumbuhan ekonomi nasional. Pada tahun 2011 pertumbuhan ekonomi kabupaten ROkan Hulu tercatat sebesar 7,60 \%. Semakin tingginya kegiatan ekonomi masyarakat Rokan Hulu berbasis pada sektor pertanian dan sektor pertambangan ini terjadi karena didukung oleh jumlah tenaga kerja dan investasi yang terdistribusi dalam sektor-sektor tersebut. Kabupaten Rokan Hulu merupakan penghasil kelapa sawit dalam bidang Pertanian sebesar dan sektor Industri Pengolahan yang telah memberikan kontribusi terbesar bagi pembentukan PDRB Kabupaten Rokan Hulu Penyumbang terbesar dengan persentase 51.57\%. Di samping itu melalui PDRB perkapita juga mengalami kenaikan. Ini berarti masyarakat Rokan Hulu mengalami kenaikan produksi di semua sektor lapangan usaha. Sedangkan pendapatan perkapita juga naik ratarata sebesar PDRB perkapita di mana ini berarti kemakmuran masyarakat Rokan Hulu secara garis besar telah mengalami kenaikan. Sektor pengangkutan dan komunikasi menjadi sektor dengan pertumhbuhan kedua terbesar yaitu sebesar 10,81\% semakin tingginya kebutuhan akan sektor angkutan dan komunikasi berbanding lurus dengan pertumbuhan ekonomi. Kabupaten Rokan Hulu hanya mengandalkan angkutan jalan raya sebagai sarana angkutan masyarakat. Walaupun Rokan Hulu memiliki beberapa sungai besar yaitu Sungai Rokan Kanan dan Sungai 
Rokan Kiri namun tidak digunakan sebagai sarana angkutan.Mobilitas masyarakat Rokan Hulu antar kecamatan dan antar kabupaten/kota membuat suburnya angkutan umum jalan raya.Sedangkan sektor komunikasi disumbangkan terbesar oleh sub sektor pos dan telekomunikasi.Hal ini disebabkan oleh kemajuan teknologi komunikasi yang diikuti oleh masyarakat Rokan Hulu. Pertumbuhan terbesar ketiga yaitu sektor industri pengolahan yang disumbangkan hanya untuk sub sektor indusri tanpa migas yaitu sebesar $9,41 \%$.

\section{Kinerja Pelayanan Publik}

Secara umum indeks pelayanan public dapat dilihat dari IPM (Indeks Pembangunan Manuasia) dengan melakukan perbandingan pengukuran dari angka harapan hidup, angka melek huruf, tingkat pendidikan, dan standar hidup untuk menentukan pengaruh kebijakan ekonomi terhadap kualitas hidup. IPM Rokan Hulu dari tahun 2013 sampai tahun 2017 terus naik. IPM Kabupaten Rokan Hulu terus naik karena terus adanya perbaikan untuk sektor-sektor yang menjadi indikator pembangunan manusia kabupaten ini. Contohnya adalah meningkatkan sarana dan juga prasarana pendidikan seperti sekolah, guru, dan akses jalan ke sekolah, begitu juga dengan sarana dan prasarana untuk meningkatkan kesehatan masyarakat. Secara umum perbandingan IPM di Kabupaten Rokan Hulu dan Kampar serta di propinsi Riau dapat dilihat dari grafik beikut:

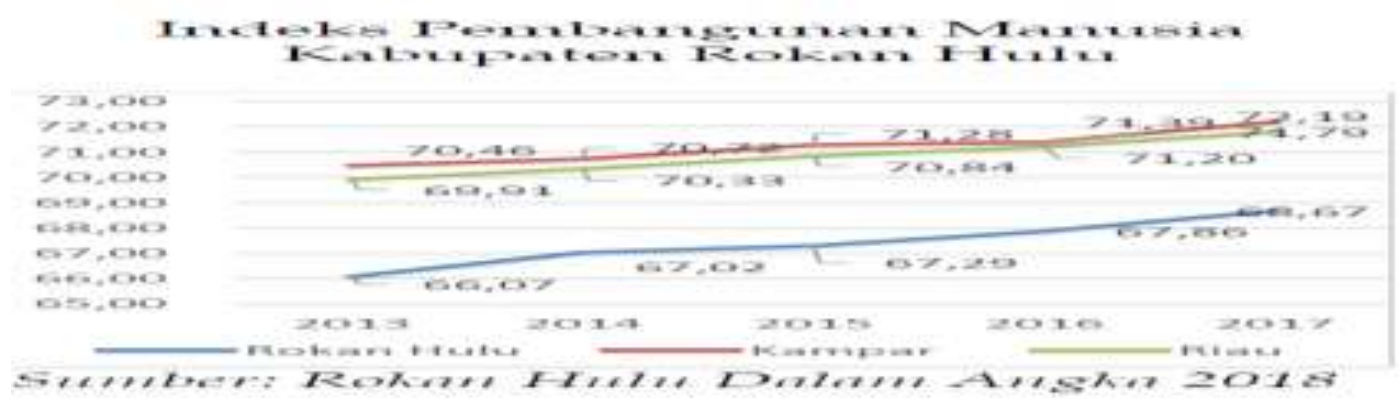

Dari grafik IPM di atas dapat dilihat bahwa angka IPM Kabupaten Rokan Hulu masih di bawah angka IPM Provinsi Riau. Sedangkan 
Kabupaten Kampar yang merupakan induk dari Kabupaten Rokan Hulu angka IPMnya sudah lebih baik dan berada di atas angka Provinsi Riau. Jumlah penduduk miskin di Kabupaten Rokan Hulu terus mengalami kenaikan dari tahun 2013- 2017. Kenaikan jumlah penduduk miskin dapat dilihat pada grafik berikut:

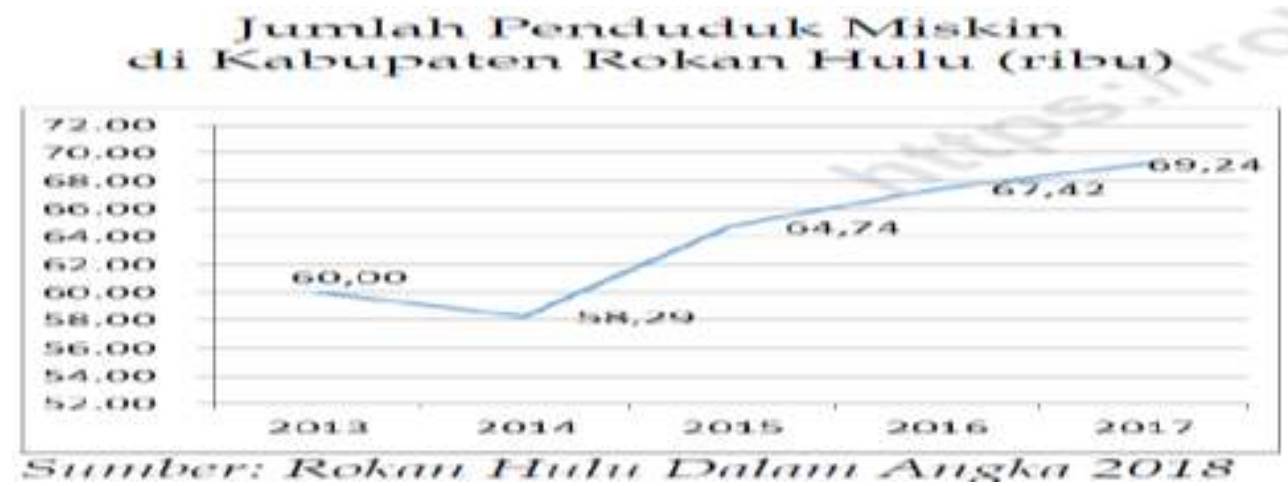

Perbandingan dengan kabupaten kampar daoat dilihat dalam tabel berikut:

\begin{tabular}{cccc}
\hline \hline & & \multicolumn{2}{c}{$\begin{array}{c}\text { Penduduk Miskin } \\
\text { Number of Poor People }\end{array}$} \\
$\begin{array}{c}\text { Tahun } \\
\text { Year }\end{array}$ & $\begin{array}{c}\text { Garis Kemiskinan Poverty } \\
\text { Line (rupiah) }\end{array}$ & $\begin{array}{c}\text { Jumlah } \\
\text { (000 Jiwa) } \\
\text { Total }\end{array}$ & $\begin{array}{c}\text { Persentase } \\
\text { Percentage }\end{array}$ \\
\hline$(1)$ & $(2)$ & $(3)$ & $(4)$ \\
\hline 2011 & 308446 & 61,2 & 8,52 \\
2012 & 320907 & 62,3 & 8,36 \\
2013 & 336681 & 68,6 & 9,04 \\
2014 & 348373 & 67,6 & 8,68 \\
2015 & 360324 & 72,2 & 9,17 \\
\hline & 375716 & 67,7 & 8,38 \\
\hline
\end{tabular}

Sumber/Source: Survei Sonlai Ekonomi Nasional//Notionol Sorio Economic Survey

Dari kedua grafik diatas Jumlah penduduk miskin di Kabupaten Rokan Hulu dan Kampar terus mengalami kenaikan dari tahun 20132017. Angka kemiskinan di Kedua daerah ini hampir sama yakni 67,7 
untuk kabupaten Kampar dan 69,24 untuk kabupaten Rokan Hulu. Dibandingkan dengan propinsi Riau dapat dilihat dalam table berikut:

\section{Persentase Penduduk Miskin Provinsi Riau Tahun 2012 Berdasarkan Kabupaten}

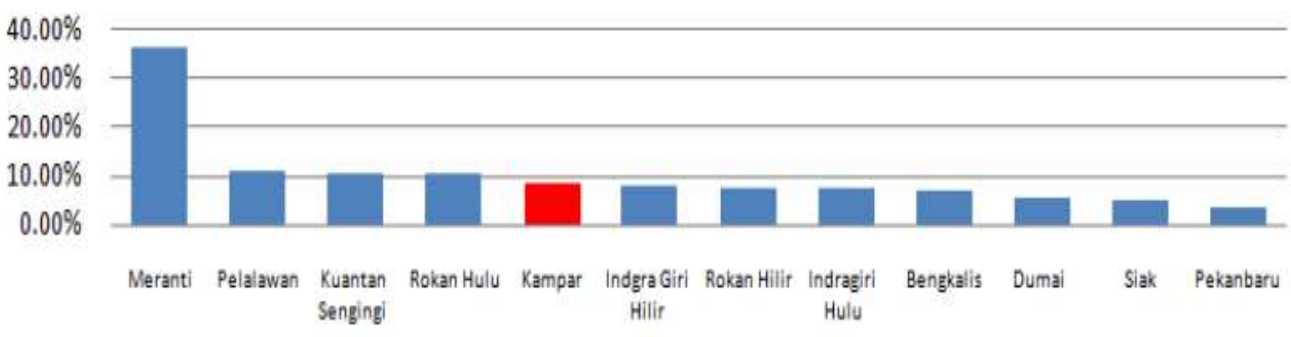

Keberadaan angka kemiskinan tersebut tidak lepas dari upaya pemerintah daerah kabupaten Kampar, untuk menekan angka kemiskinan tampaknya terus diupayakan. Program zero kemiskinan tahun 2016, yang dicanangkan oleh kabupaten Kampar, dengan menggerakkan peningkatan ekonomi kerakyatannya. Namun, tampaknya, implementasi program kemiskinan tersebut belum optimal menekan angka kemiskinan yang ada didaerah. Meskipun secara persentase penduduk miskin di kabupaten Kampar menurun. Data Badan Pusat Statistik (BPS) tahun 2012, menunjukkan trend angka kemiskinan terus menurun. Tahun 2010, 10,47 persen, kemudian tahun 2011 kemiskinan dikampar mampu ditekan menjadi 8,52 persen, kemudian tahun 2012 angka kemiskinan menjadi 8,36 persen. Program kemiskinan yang diim-plementasikan belum mampu mem-pertahankan penurunan angka kemiskinan secara konsisten. Dimana tahun 2012, pemerintah daerah kabupaten Kampar mampu menurunkan angka kemiskinan hanya 0,16 persen. Berbeda dengan tahu 2011, indek kemiskinan daerah Kampar mampu menurun mencapai 2,1 persen.

Selanjutnya, dalam hal kinerja pelayanan public bidang pendidikan ditandai dengan jumlah fasilitas pendidikan dan rasio antara guru dan jumlah sekolah. Jumlah sekolah yang ada di kabupaten rokan Hulu dapat dilihat sebagai berikut: 


\begin{tabular}{|c|c|c|c|c|c|c|}
\hline \multirow[t]{2}{*}{ Jenjang } & \multicolumn{2}{|c|}{$\begin{array}{l}\text { Jumlah } \\
\text { Sekolah }\end{array}$} & \multicolumn{2}{|c|}{ Jumlah Murid } & \multicolumn{2}{|c|}{ Jumlah Guru } \\
\hline & Rohul & Kampar & Rohul & Kampar & Rohul & Kampar \\
\hline SD & 383 & 487 & 78.500 & 102.307 & 4.645 & 6908 \\
\hline SMP & 174 & 99 & 30.500 & 30.512 & 2.874 & 2547 \\
\hline SMA & 119 & 49 & 19.386 & 15.955 & 1.132 & 1.399 \\
\hline
\end{tabular}

Dari segi kemampuan keuangan sampai saat ini, pendapatan daerah kabupaten Kampar, masih bergantung kepada dana perimbangan. Sementara Pendapatan Asli Daerah (PAD) belum mampu berkontribusi besar terhadap pendapatn daerah. Proporsi Dana Perimbangan, rerata tahun 2010-2014 mencapai 84,32 persen. Sepanjang, priode 2010-2014 itu, tidak pergeseran ketergantungan pemerintah daerah terhadap dana perimbangan, bahkan tahun 2014 diproyeksi dana perimbangan mencapai 85,46 persen. Lain-lain pendapatan daerah yang sah, secara proporsi merangkak naik, namun komponen pendapatan terbesar tetap dari dana perimbangan. Sementara Pendapatan Asli Daerah (PAD) tampaknya gagal diolah secara optimal oleh pemerintah daerah sebagai pendapatan asli daerah. Pendapatan Asli Daerah (PAD) hanya mampu berkontribusi 6,16 persen dari total pendapatan daerah. Berbeda, proporsi Dana Perimbangan dan Lain-lain pendapatan daerah yang sah, kedua komponen pendapatan ini, secara proporsi terjadi peningkatan baik secara persentase maupun nominalnya. Sedangkan PAD, secara persentase (proporsi) justru terjadi pergerakan yang fulktuatif (tidak setabil). Bahkan, secara nominal (angka riil) juga terjadi hal serupa (naik turun). Tahun 2010, realisasi PAD sebesar Rp.100,9 milyar, sementara tahun 2011 pemerintah dinilai gagal mengelola PAD secara optimal, hal itu ditunjukkan dengan penurunan realisasi PAD tahun 2011 yang hanya sebesar Rp. 96,9 milyar. Meskipun pada tahun berikutnya (2012-2013) 
realisasi PAD meningkat masing Rp. 110 milyar dan Rp. 157,8 milyar. Pemerintah daerah dalam menargetkan PAD sebagai komponen pendapatan daerah tidak realistis dengan kondisi sebenarnya. Tahun 2014 PAD ditargetkan sebesar Rp. 120,6 milyar, atau 5,5 persen dari total pendapatan daerah. Angka proyeksi tersebut menurun dari realiasi tahun tahun 2013 realiasi PAD mencapai 157, 8 miliyar. Padahal, pemerintah daerah selalu menetapkan APBD diakhir tahun, bahkan sudah masuk tahun anggaran berjalan (januari-februari), seharusnya pemerintah dapat memproyeksi secara benar dan mendekati angka sebenarnya.

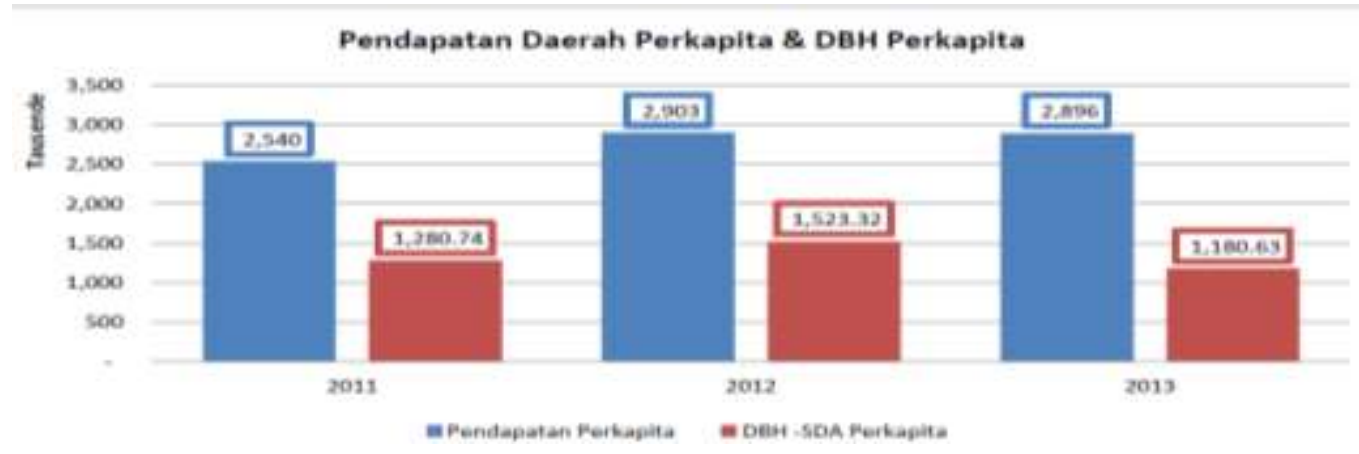

Pendapatan daerah perkapita di kabupaten Kampar, tergolong tinggi. Tiga tahun terakhir rerata pendapatan daerah perkapita mencapai Rp. 2,7 juta. Untuk trend pendapatan daerah perkapita mengikuti trend peningkatan pendapatan daerah secara. Tahun 2011 misalnya pendapatan daerah perkapita mencapai Rp. 2,5 juta, sedangkan tahun 2012 meningkat menjadi Rp. 2,9 juta/kapita. Namun terjadi penurunan pada tahun 2013 realisasi menjadi Rp. 2,8 juta / kapita6. Sama halnya dengan DBH - SDA perkapita, kabupaten Kampar dikategorikan daerag yang yang relative tinggai. Angka pendapatan DBH -SDA perkapita diatas rata-rata pendapatan DBH SDA nasional. Rerata DBH -SDA perkapita nasional tahun 2009-2012 DBH SDA nasional hanya sebesar Rp. 268,7 ribu. Sementara kabupaten Kampar DBH-SDA perkapita mencapai rerata 2011-2013 mencapai Rp. 1,3 juta. Tingginya pendapatan daerah perkapita justru tingkat kemiskinan di kabupaten Kampar masih tergolong tinggi, diatas rata-rata kemiskinan provinsi Riau. Tahun 2012 kemiskinan 
dikabupaten Kampar sebesar 8,35 persen sementara kemiskinan provinsi Riau sebesar 8,05 persen. Besarnya kontribusi pendapatan daerah yang berasal Dana Bagi Hasil (DBH) Sumberdaya Alam, mempengaruhi besar kecilnya kemampuan fiskal yang dimiliki daerah kabupaten Kampar. Ruang fiskal daerah, kabupaten Kampar, rerata tahun 2010-2014 Proyeksi, terdapat lebih dari 42 persen pendapatn daerah yang masih fleksibel/bebas untuk digunakan daerah sebagai penunjang pembangunan dan pemerataan pembangunan antar wilayah. Proyeksi tahun 2014 (melalui APBD Murni) ruang fiskal daerah kabupaten Kampar, mecapai 44 persen lebih, pendapatan daerah yang masih leluasi digunakan untuk membiyai pembangunan.

Dalam aspek belanja, realisasi belanja modal cenderung rendah setiap tahun, sementara belanja pegawai realisasinya cenderung tinggi. Rerata tahun 2010-2013, realisasi belanja pegawai mencapai 95,7 persen setiap tahunnya. Sementara belanja modal rerata ditahun yang sama, hanya mampu terealisasi mencapai 85,3 persen. Untuk belanja barang jasa, rerata setiap tahunnya hanya mampu terserap 88,8 persen. belanja lainnya, seperti bantuan keuangan, bansos, hibah, subsidi, cenderung tinggi reraa ditahun yang sama pula terealiasi mencapai 92,2 persen. Jika dilihat tahun 2013, saja justru belanja modal hanya teralisasi 75,04 persen dari total belanja modal yang direncanakan ditahun itu. Sementara belanja pegawai mampu teralisasi mencapai 94,21 persen. ini artinya, kecenderungan pemerintah daerah dalam membelanjakan uangnya justru lebih getol dalam membelanjakan APBD untuk gaji dan tunjangan aparatur, sementara untuk belanja publik yang berkorelasi dengan pertumbuhan ekonomi malah lemah dalam pelaksanaannya. Realisasi belanja daerah kabupaten Kampar dapat dilihat pada table berikut: 


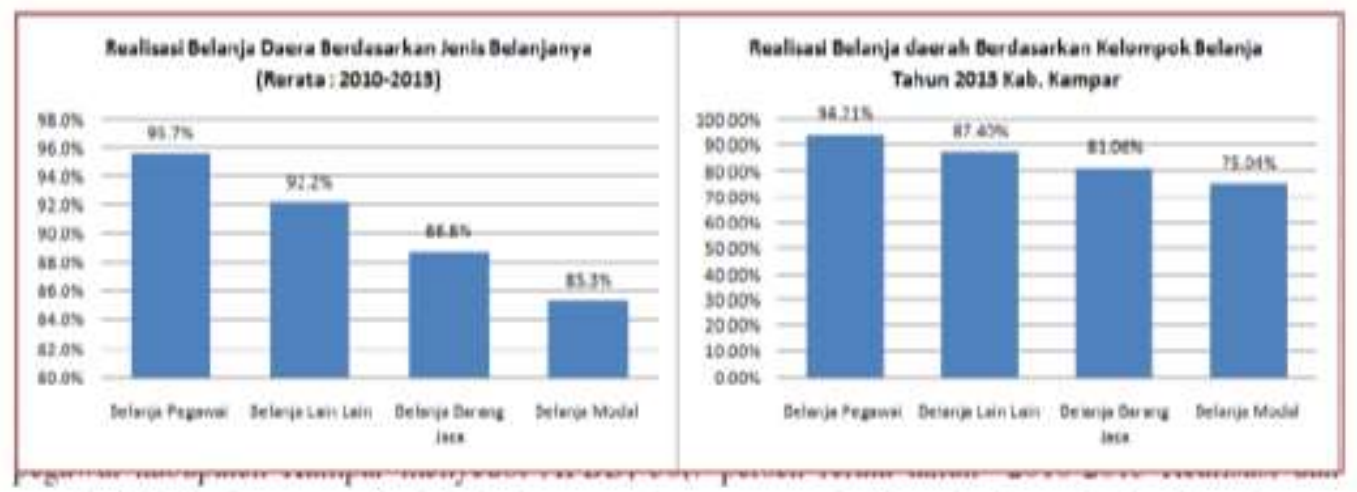

\section{B. Faktor Yang Mempengaruhi Tingkat Kesejahteraan Di Daerah Rokan Huu sebagai Kabupaten Pemekaran Di Propinsi Riau}

Pada dasarnya setiap masyarakat dalam hidup akan mengalami perubahan-perubahan. Perubahan dalam masyarakat berproses secara terus menerus dan tidak dapat dinyatakan oleh salah satu faktor saja. Dengan demikian migrasi bukan satu-satunya faktor yang memicu perubahan sosial. Namun berdasarkan fenomena tentang tingkat migrasi yang cukup tinggi di Kab. Rokan Hulu terdapat asumsi perubahan sosial yang terjadi berakselerasi dengan tingkat migrasi. Perubahan sosial yang ingin dikaji dalam penelitian ini adalah dalam aspek sosial budaya dan sosial ekonomi dengan indikator-indikator tertentu. Perubahan sosial dalam perspektif budaya mencakup perubahan kelompok sosial, institusi sosial, stratafikasi sosial serta sistem nilai yang dianut. Perubahan dalam kelompok sosial akan mempengaruhi korelasi antara pergaulan hidup individu dengan kelompok sosial baik dalam bentuk kelompok keluarga serta organisasi masyarakat di berbagai bidang kehidupan seperti ekonomi, politik, kesenian dan keagamaan. Sementara perubahan dalam perspektif ekonomi mencakup perubahan sistem produksi, distribusi dan konsumsi, pertumbuhan income per kapita, serta perubahan pokok-pokok kegiatan ekonomi dalam memenuhi kebutuhan hidup sehari-hari. Selama kurun waktu 1979-2006 telah terjadi berbagai momentum yang mempengaruhi kehidupan sosial masyarakat Kab. Rokan Hulu. Berdasarkan paradigma pemikiran dan fenomena migrasi di atas maka 
menarik untuk dikaji tentang pengaruh migrasi terhadap perubahan sosial yang ada di Kab. Rokan Hulu.

Hal ini disebabkan terciptanya ekstensifikasi kultur agraris di wilayah Kab. Rokan Hulu keberadaan beberapa perkebunan kelapa sawit di Kab. Rokan Hulu menjadikan daerah ini menjadi primadona tujuan migrasi. Sektor perkebunan menyediakan lapangan pekerjaan yang cukup luas di tengah kesulitan masyarakat di berbagai wilayah untuk mencari nafkah. Secara demografi keadaan ini menciptakan perubahan komposisi kependudukan dengan meningkatnya arus migrasi ke berbagai Kecamatan di Kab. Rokan Hulu. Ribuan hektar kawasan hutan telah disulap menjadi sentra produksi berbagai komoditas baru seperti kelapa sawit. Sektor ini telah menjadi primadona baru karena penggarapannya secara lebih luas dengan berbagai sistem dan kebijakan pengelolaan yang diterapkan pemerintah. Hingga tahun 2005 tercatat luas areal perkebunan kelapa sawit, karet, kopi dan beberapa komoditas lainnya di Kab. Rokan Hulu telah mencapai 263.526 Ha. Sektor perkebunan ini dikelola dengan menggunakan pola swadaya, Unit Pelayanan dan Pengembangan (UPP), Perkebunan Inti Rakyat (PIR) baik oleh BUMN maupun Kemitraan. Disamping itu pola migrasi kabupaten Rokan Hulu diawali dengan kebijakan pemerintah dalam redistribusi penduduk. Pola tersebut dikenal dengan transmigrasi. Transmigrasi merupakan program kegiatan penting dalam rangka memecahkan persoalan yang berkaitan dengan kependudukan di Indonesia.

Pada masa kolonial, Pemerintah Belanda telah memulai kegiatan transmigrasi dalam tahun 1905 dengan memindahkan 229.959 jiwa dari pulau Jawa ke daerah Lampung. Bagaimanapun juga kwalitas dan kwantitas program transmigrasi pada era ini telah menorehkan sejarah penting migrasi di Indonesia yang diprogramkan oleh pemerintah. Pada masa pemerintahan Republik Indonesia yang mulai stabil sejak 1950, perhatian akan transmigrasi berlanjut dengan memukimkan 23 keluarga. Namun hingga tahun 1959 program ini belum berjalan dengan mantap 
karena tidak direncanakan dengan baik. Persoalan belanja, penyiapan lahan dan pembinaan lapangan hampir tidak pernah dikaji sungguhsungguh dalam upaya pemindahan penduduk tersebut. Pada saat ini pada umumnya para peserta transmigrasi terlantar sehingga menimbulkan gambaran yang menakutkan bagi program transmigrasi. ${ }^{4}$

Langkah-langkah perbaikan program transmigrasi dimulai dalam tahapan PELITA I,II yang berpuncak pada PELITA III dengan keluarnya UU no. 3 tahun 1973 tentang ketentuan pokok-pokok Transmigrasi. Melalui perangkat undang-undang ini penduduk tempatan dilibatkan secara sukarela dengan diberikan kesempatan secara suka rela untuk ikut dalam program transmigrasi. Meskipun demikian tidaklah secara teknis segala persoalan diselesaikan dengan sempurna. Perbaikan program transmigrasi semakin menuntut perubahan seiring semakin besar tantangan yang ditemukan di lapangan. Persoalannya tidak hanya tebatas pada para transmigran umum yang berasal dari pulau Jawa, namun juga penduduk lokal yang mengikuti program tersebut. ${ }^{5}$

Gagasan untuk mengikutkan penduduk lokal dalam program transmigrasi didasari dengan pertimbangan untuk percepatan pengembangan roda pembangunan daerah. Dengan program ini maka penyerapan anggaran pembangunan tidak hanya diarahkan pada daerah yang mengalami krisis sosial saja namun juga penduduk di sekitar daerah transmigrasi. Meskipun penduduk lokal hanya $10 \%$ dari transmigran umum yang menempati daerah transmigrasi namun memberikan pengaruh dalam kehidupan pemukiman wilayah transmigran tersebut.

Bertemunya transmigran lokal dengan transmigran umum yang datang dari berbagai daerah sekaligus juga mempertemukan nilai-nilai sosial budaya masing-masing pihak. Terjadinya interaksi sosial budaya berkembang menjadi sistem tata nilai positif dan negatif. Efek positif dapat diukur bila dalam interaksi ini dapat menghubungkan dan membuat

\footnotetext{
${ }^{4}$ UU. Hamidiy, Membaca Kehidupan Orang Melayu, Bumi Pustaka, Pekanbaru: 1986, hlm. 181-182

${ }^{5} \mathrm{Ibid}, \mathrm{hlm} .182$
} 
persaudaraan antara etnik yang berbeda. Namun di sisi lain ketegangan hubungan sosial sering menjurus dalam bentuk benturan fisik yang menjadi efek negatif dari sistem ini. dalam proses interaksi seringkali masing-masing sistem berupaya survive sehingga menimbulkan iklim pertentangan dan menajamnya hubungan sosial. ${ }^{6}$

Dalam perspektif ini dapat ditemukan tiga kategori dari masyarakat transmigran lokal. Pertama, transmigran yang bertahan di lokasi transmigrasi, dapat menyesuaikan diri dengan pendatang dan bahkan dapat menguasai bahasa sehingga berkomunikasi dengan baik, biasanya mereka ikut menikmati kesuksesan program ini bersama transmigran umum. Mereka relatif dapat bekerja dengan baik serta memanfaatkanpengalaman positif yang didapat dari warga lainnya demi kepnetinga bersama. Kedua kelompok transmigran yang bertahan namun kurang dapat berinteraksi dengan baik sehingga cenderung membentuk kelompok tersendiri. Jarak sosial yang tercipta demikian berlarut dan tetap bertahan dengan harapan mereka dapat mempertahankan perbedaan sosial budaya sebagai masyarakat lokal. Kelompok ketiga para transmigran lokal yang meninggalkan lokasi transmigrasi dengan berbagai pertimbangan mereka akan masalah kehidupan yang dihadapi. Kelompok ini sangat sulit untuk berakulturasi. Disamping masalah ini teknis penyelenggaraan, kesuburan lahan serta sistempembinaan yang tidak memuaskan menyebabkan para transmigran meninggalkan daerah transmigrasi. ${ }^{7}$

Sub sektor tanaman perkebunan memiliki angka pertumbuhan terbesar. Sesuai dengan kontur tanah dan iklim di Kabupaten Rokan Hulu maka perkebunan menjadi lahan pertanian yang diutamakan di Kabupaten Rokan Hulu baik dikelola oleh perusahaan maupun oleh rakyat. Terkait dengan migrasi, mata pencaharian hidup setiap masyarakat mempunyai kesempatan yang sama di dalam bidang ekonomi. Masyarakat tidak

\footnotetext{
${ }^{6}$ Ibid.hlm. 184-185

${ }^{7}$ Ibid.,hlm. 186-187
} 
pernah membedakan ia berasal dari suku/etnis apa namun yang terpenting adalah mempunyai skill dan kemampuan yang dibutuhkan.

Namun demikian perubahan budaya agraris tradisional menjadi industri yang dipicu perubahan dalam tata kelola tanaman perkebunan menyebabkan perubahan lahan pertanian yang beralih fungsi menjadi perkebunan sawit untuk industri. Hasil wawancara menunjukkan bahwa perubahan lahan baik pertanian atau pun lahan kosong menjadi kawasan industri pertanian di satu sisi menjanjikan kesejahteraan dengan tersedianya lapangan pekerjaan. Namun secara mendasar dalam pemenuhan kebutuhan ekonomi masyarakat hilangnya potensi hutan yang sangat bermanfaat bagi kehidupan masyarakat dan menjadi pokok mata pencaharian masyarakat sebelumnya turut menimbulkan banyak persoalan. Dengan berkembangnya industri perkebunan menyebabkan berkurangnya kesempatan masyarakat akan penguasaa lahan yang pada umumnya telah dikuasai oleh perusahaan.

\section{Kesimpulan}

Dari berbagai uraian diatas dapat disimpulkan bahwa :

1. kabupaten Rokan Hulu pasca Reformasi telah berkembang menjadi daerah yang tidak hanya mampu menyusul berbagai indicator kesejahteraan dari wilayah induknya kabupaten Kampar namun juga bahkan akulturasi budaya masyarakat pendatang telah menempatkan kabupaten ini menjadi mandiri. Hal ini terlihat dari dua indicator utama yaitu Kinerja Ekonomi Daerah dan pelayanan publik.

2. Kinerja pertumbuhan ekonomi paling utama adalah pertumbuhan ekonomi yang dapat menjadi acuan data mengenai arah perekonomian daerah tersebut. Pertumbuhan ekonomi yang baik juga harus diikuti oleh pemerataan kesejahteraan masyarakatnya. Pertumbuhan ekonomi Kabupaten Rokan Hulu pada tahun 2017 lebih baik dibandingkan tahun 2016. Dari 3 sektor yang memiliki share yang tertinggi terhadap perkonomian di Kabupaten Rokan Hulu juga 
menunjukkan keadaan yang lebih baik dibandingkan tahun sebelumnya. Pertumbuhan ekonomi Kabupaten Rokan Hulu pada tahun 2017 sebesar 5,56 persen. Dalam perspektif ekonomi kabupaten Rokan Hulu setelah otonomi daerah menunjukkan laju pertumbuhan ekonomi yang cukup besar bahkan di atas rata-rata pertumbuhan ekonomi nasional. Pada tahun 2017 pertumbuhan ekonomi kabupaten ROkan Hulu tercatat sebesar 7,60 \%.

3. Dari Kinerja Pelayanan Publik Secara umum indeks pelayanan public dapat dilihat dari IPM (Indeks Pembangunan Manuasia) dengan melakukan perbandingan pengukuran dari angka harapan hidup, angka melek huruf, tingkat pendidikan, dan standar hidup untuk menentukan pengaruh kebijakan ekonomi terhadap kualitas hidup. IPM Rokan Hulu dari tahun 2013 sampai tahun 2017 terus naik. IPM Kabupaten Rokan Hulu terus naik karena terus adanya perbaikan untuk sektor-sektor yang menjadi indikator pembangunan manusia kabupaten ini. Contohnya adalah meningkatkan sarana dan juga prasarana pendidikan seperti sekolah, guru, dan akses jalan ke sekolah, begitu juga dengan sarana dan prasarana untuk meningkatkan kesehatan masyarakat. Di samping itu umlah penduduk miskin di Kabupaten Rokan Hulu dan Kampar terus mengalami kenaikan dari tahun 2013- 2017. Angka kemiskinan di Kedua daerah ini hampir sama yakni 67,7 untuk kabupaten Kampar dan 69,24 untuk kabupaten Rokan Hulu. Keberadaan angka kemiskinan tersebut tidak lepas dari upaya pemerintah daerah kabupaten Kampar, untuk menekan angka kemiskinan tampaknya terus diupayakan. Selanjutnya, dalam hal kinerja pelayanan public bidang pendidikan ditandai dengan jumlah fasilitas pendidikan dan rasio antara guru dan jumlah sekolah yang sembang antara kedua kabupaten. 


\section{DAFTAR PUSTAKA}

A.A.G. Peters \& Koesriani S, (ed.), Hukum dan Perkembangan Sosial, Buku II, (Jakarta: 1998, Pustaka Sinar Harapan)

Abdul Ghofur Anshori, Filsafat Hukum Sejarah, Aliran Dan Pemaknaan, (Yogyakarta: 2006, Gadjah Mada University.Press)

Afan Gaffar, Politik Indonesia, Transisi Menuju Demokrasi, Cet. Ke-6, Pustaka Pelajar, Yogyakarta, 2006.

Ateng Syafruddin, Pasang Surut Otonomi Daerah, (Jakarta: 1985, Binacipta)

Bagir Manan, Hubungan Pusat dan Daerah Menurut UUD 1945, (Jakarta:1990 Sinar Harapan)

BAPPENAS, Studi Evaluasi Dampak Pemekaran Daerah 2001-2007, (Jakarta: 2008, Bulidng and Reinventing Decentralised Governance - BRIDGE kerjasama dengan UNDP)

Emeritus John Gilissen, \& Emeritus Frits Gorle, Sejarah Hukum, (Bandung: 2005, Penerbit PT Refika Aditama)

Eric Barendt, An Introduction to Constitutional Law, (New york: 1998, Oxford University Press Inc)

Hans Kelsen, General Theory of Law and State, translated by: Anders Wedberg, (New York: Russell \& Russell, 1961)

Jimly Asshiddiqie, Konstitusi \& Konstitusionalisme Indonesia, Edisi Revisi, (Jakarta: 2005, Konstitusi Press)

John Henry Merryman, The Civil Law Tradition, (Stanford : 1968, Stnaford University Press)

Lembaga Administrasi Negara (LAN), Pusat Kajian Kinerja Otonomi Daerah. 2005“Laporan Evaluasi Penyelenggaran Otonomi Daerah Periode 1999- 2003”, Jakarta, 2005.

M. Mahfud, MD., Politik Hukum di Indonesia, (Jakarta: 2008, Raja Grafindo Persada)

---, Demokrasi dan Konstitusi di Indonesia, Studi Tentang Interaksi

Politik dan Kehidupan Ketatanegaraan, Cet. Ke-2, PT. Rineka Cipta, Jakarta, 2003.

Muslehuddin, Filsafat Hukum Islam dan Pemikiran Orientalis; Studi Perbandingan Sistem Hukum Islam. Terjemah oleh Yudian Wahyudi Asmin, (Yogyakarta: 1991, Tiara Wacana)

R Soedirman Kartohadiprodjo , Refleksi tentang Struktur IImu Hukum, (Bandung: 1999, Mandar Maju)

R. Tresna, t.t., Bertamasya Ke Alam Ketatanegaraan, (Bandung: t.th., Dibya. (t.t.: 32-36)

Riswanda Imawan, Membedah Politik Orde Baru , (Yogyakarta: 1997, Pustaka Pelajar)

Roelof $\mathrm{H}$. Heveman, The Legality of Adat Criminal Law in Modern Indonesia, (Jakarta: 2002, Tata Nusa)

Satjipto Raharjo, IImu Hukum, (Bandung: 1991, Citra Aditya Bakti)

Sidharta, Karakteristik Penalaran Hukum dalam Konteks Keindonesiaan, (Bandung: 2006, C.V. Utomo) 
Sudjarwo MS, Metodologi Penelitian Sosial, Mandar Maju, Bandung, 2001.

Sujamto, Otonomi Daerah yang Nyata dan Bertanggung Jawab, (Jakarta: 1990, Ghalia Indonesia)

Suwardi, MS dkk., Sejarah Perjuangan Rakyat Riau, Buku II, (Pekanbaru: 2004, Unri Press)

Tri Ratnawati, Pemekaran Daerah; Politik Lokal dan Beberapa Isu Terseleki (Yogyarta: 2009, Pustaka Pelajar)

W. Poespoprodjo, Filsafat Moral; Kesusilaan dalam Teori dan Praktek (Bandung: 1999, Pustaka Grafika) 